\title{
Tree height and species composition of young forest stands fifteen years after the large-scale wind disturbance in Tatra National Park
}

\author{
Vladimír Šebeň ${ }^{1 *}$, Bohdan Konôpka ${ }^{1,2}$ \\ ${ }^{1}$ National Forest Centre - Forest Research Institute Zvolen, T. G. Masaryka 2175/22, SK - 96001 Zvolen, Slovak Republic \\ ${ }^{2}$ Czech University of Life Sciences Prague, Faculty of Forestry and Wood Sciences, Kamýcká 129, \\ CZ-16500 Praha 6-Suchdol, Czech Republic
}

\begin{abstract}
In November 2004, the windstorm Alžbeta damaged over 12 thousand ha of forests in the High Tatra Mts. It was the largest wind disaster in the modern forestry history of Slovakia. The process of forest regeneration at the postdisturbance area has to be monitored together with the effectiveness of implemented forestry measures. Therefore, we focused on tree measurements at 90 monitoring plots (MP) in $1 \times 1 \mathrm{~km}$ net placed in the post-disturbance area in the Tatra National Park. We recorded tree species, number of trees (density) and tree heights. Besides that, stem diameters of trees with breast height diameter over $7 \mathrm{~cm}$ were measured. The field work was performed in the growing season of 2019, i.e. about 15 years after the wind disturbance. In total, 20 tree species, 15 broadleaves and 5 coniferous ones, were recorded at MP. The most frequent (28.9\% of all trees) species was Norway spruce followed by silver birch (18.6\%), rowan (16.9\%) and goat willow (15.2\%). Four species, i.e. European larch, wild cherry, grey alder and common alder contributed to the total number of trees between 1.8 and $4.8 \%$ each. Share of all other species together was about $5 \%$. Tree height frequency was left-sided for the whole sampling set (all species together), as well as for individual species. Most of young trees were less than $1 \mathrm{~m}$ high, but some of them exceeded $10 \mathrm{~m}$. Further, tree density of over 100 individuals per are $\left(100 \mathrm{~m}^{2}\right)$ was found at $1 / 3$ of all MPs. As many as $25 \%$ of MPs were characterized with tree densities between 61 and 90 individuals. At $23 \%$ of MPs, the number of trees was up to 30 individuals per are, and $20 \%$ of MPs had between 31 and 60 small trees per are. The results suggested that the post-disturbance forest stands in the High Tatras would be more resistant to wind storms and very probably also to bark beetles after reaching maturity than those, which were destructed and declined at the beginning of $21^{\text {st }}$ century.
\end{abstract}

Key words: post-disturbance area; forest regeneration; young forest stands; tree density; tree species

Editor: Jaroslav Holuša

\section{Introduction}

Both historically and recently, wind storms have become the most serious destructive factor in the prevailing part of boreal and temperate forests in Europe (Seidl et al. 2014). Risk of wind disturbance in forests is increasing not only with the rising severity of the harmful agent (due to inherent phenomena of climate change) but also with the status of forest stands, specifically their stability. i.e. resistance to destruction. The risk of disturbance increases with the increase of tree aboveground biomass stock, at the same time, more wood volume per hectare can be damaged during a single episode (Mitchel 2013). It is generally known that standing stocks of forests have been substantially increasing especially in the regions of Western, Central and Northern Europe for the last five decades (Gregow et al. 2017). For instance, stand- ing stock of Slovak forests almost doubled between the years 1980 and 2018 (Ministry of Agriculture and Rural Development of the Slovak Republic 2019).

As for the conditions of Slovakia, two extremely large windstorm disturbances happened in the $21^{\text {st }}$ century the first one on November 14 $4^{\text {th }}, 2004$ (Alžbeta) and the second one on May $14^{\text {th }}$ and $15^{\text {th }}, 2014$ (Žofia). Both windstorms destroyed prevailingly spruce-dominated mature stands with the epicentre in the Tatra National Park (TANAP). The windstorm Alžbeta uprooted or broke trees in the TANAP on the area of over 12 thousand ha (Koreň 2005). In fact, it was the largest wind disaster in the modern forestry history, specifically regarding forestry evidence available since 1960 (Konôpka et al. 2016). In the TANAP, the windstorm damaged mostly stands aged between $61-120$ years, which practically dominated among local forests. These forest stands were 
rather unstable since they were composed mostly by Norway spruce, which represented about $80 \%$ of the standing stock at the end of the last century (Vološčuk et al. 1994). The windstorm Alžbeta had huge negative consequences on fulfilling a variety of ecosystem services in forests including carbon storage (Fleischer et al. 2017). Besides ecosystems services, biodiversity of plants and animals are the most valuable properties of forests and contributes to quality of life for human beings (Diaz et al. 2018). Biodiversity of forests is much influenced by disturbances whether immediately or in short time periods after destructive episodes. However, while consequences of natural disturbances to carbon balance in forests are evidently negative ones (e.g. Seidl et al. 2014), their influence on biodiversity is less known and need to be studied further in future.

Restoration of broad range of ecosystem services in forests of the TANAP depends on continuous and undisturbed processes of forest regeneration. Although, most destroyed sites were expected to be regenerated by natural processes, especially zones with higher degree of nature conservation, some places had to be promoted by foresters in the form of artificial or combined (combination of natural and man-made) reforestation (Šebeň et al. 2010a,b). At the same time, the process of forest regeneration had to be monitored to evaluate the success of forest regeneration and also the effectiveness of forestry measures, which were implemented in the area. This kind of monitoring must cover not only quantitative characteristics such as number of trees per hectare and their size, but also qualitative features especially tree species composition (Šebeň \& Konôpka 2019). In fact, only a few works focused on development of young forests following wind or other kinds of natural disturbances (e.g. Homolová et al. 2015; Szmyt \& Dobrowolska 2016; Diaci et al. 2017; Fidej et al. 2018; Orman et al. 2018). Very probably, a generalization of findings on post-disturbance forest development would require a huge bulk of results that consider a variety of factors, including a type (e.g. wind, bark beetles, fire) and a size (large-scale, small-scale, scattered etc.) of disturbances.

The goal of the paper was to analyse current tree density, species composition and tree height structure in young forest stands of the TANAP, which were established after the windstorm in November 2014.

\section{Material and methods}

\subsection{Study area}

Field survey was carried out in the TANAP (represented by the High Tatra Mts. and a part of Tatra Foothill) region. The substantial portion of the forests (cca 13 thousand ha) in this area was destroyed by a devastating windstorm called "Alžbeta" in November 2004. Main parts of damaged forests were located between 700 and 1,200 $\mathrm{m}$ a.s.l, while trees were more often uprooted than broken. Undamaged trees or stands remained within the area only sporadically. The Revitalization Project (Jankovič et al. 2007) was elaborated to ensure forest regeneration of disturbed area. The technical proposal of natural and artificial regeneration of the project included a recommendation to implement monitoring of revitalization process.

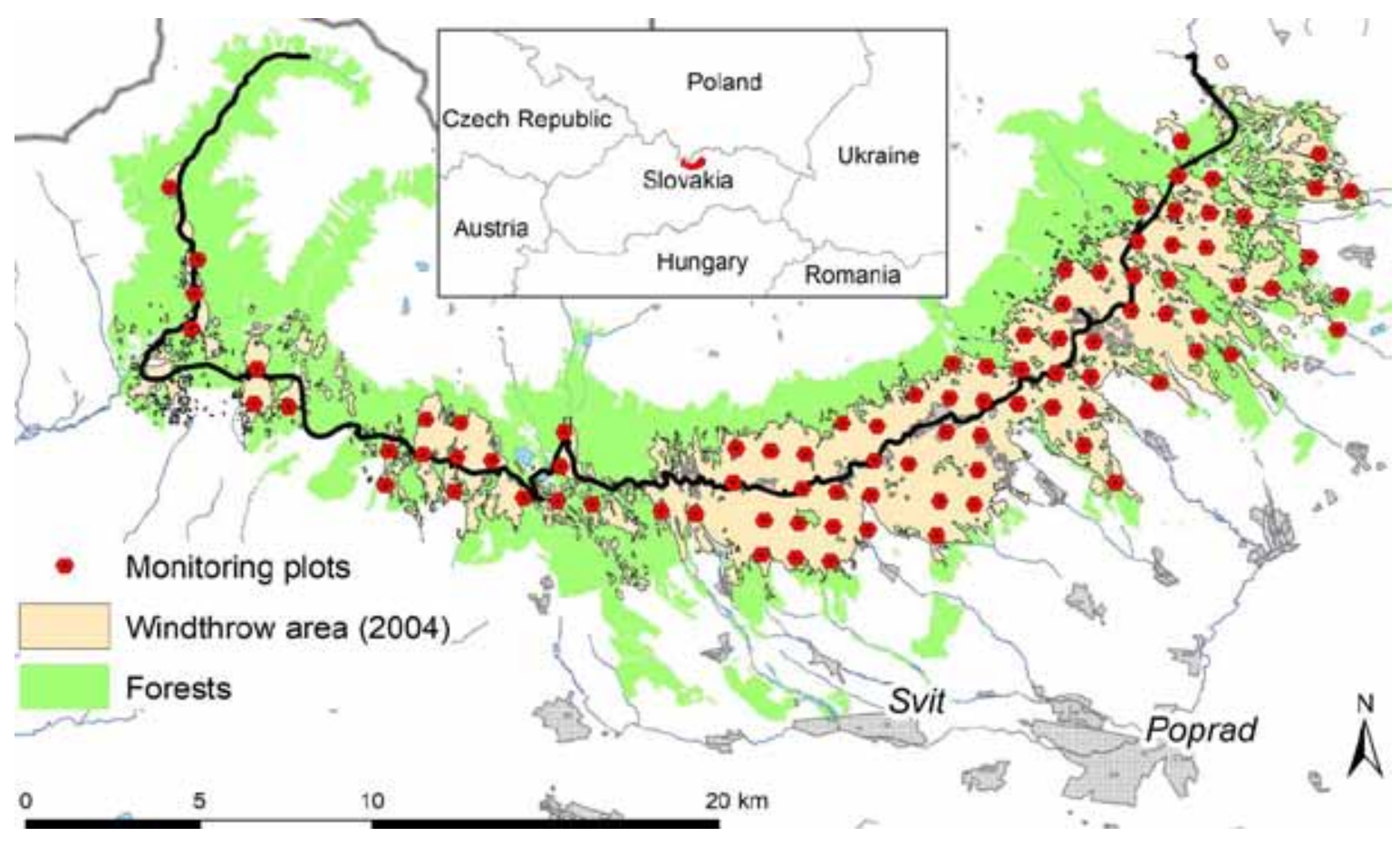

Fig. 1. Wind-damaged forests (episode in November 2004), undamaged forests and monitoring plots in the TANAP. 
Therefore, between years $2007-2008$ specialists of the National Forest Centre (NLC) established a financially exigent and a time-consuming network of monitoring plots (MP) in a regular grid of $0.5 \times 0.5 \mathrm{~km}$. The MPs were located not only in the wind calamity area, but also in the neighboring, i.e. undamaged forest stands. In total, 924 MPs were established. The area was about ten thousand hectares. This bases have been used later also for the selection of our monitoring works.

For repetitive measurements in the year 2019 we selected only the plots in spacing $1 \times 1 \mathrm{~km}$ from the basic grid of MPs. Hence, a number of our MPs was 90 (Fig. 1).

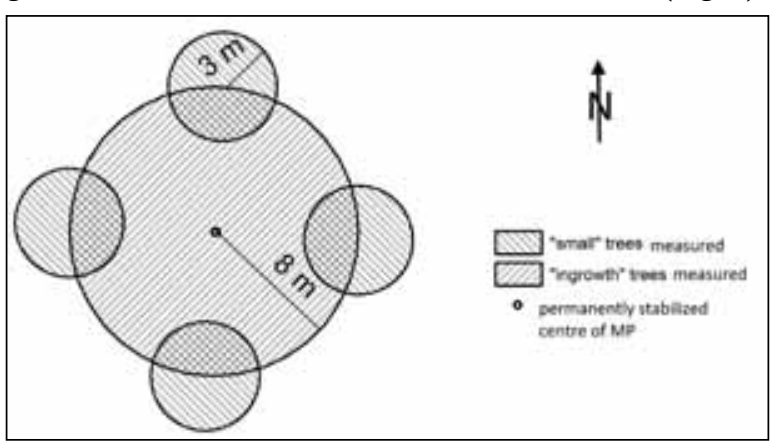

Fig. 2. Each monitoring plot (MP) was composed of central circular plot and four circular satellites, i.e. sub-plots (SP).

\subsection{Field measurements}

Field survey was conducted in spring and summer of 2019. We followed initial field survey methods and monitoring guidelines (see also Kulla et al. 2007). Our attention was focused on regeneration, i.e. young trees growing after the disturbance in 2004.

The basic sampling unit of the monitoring system is a circular MP with a constant area of $200 \mathrm{~m}^{2}$. The centre of the MP was permanently stabilized with an iron tube. The first step was to identify the MP centres in the field based on their coordinates using a GPS device with an accuracy of 3-5 meters. The second step was to find the stabilization iron tube using a metal detector.

We distinguished two categories of young trees growing after the disturbance: so called "small trees" with a diameter at breast height (DBH) up to $7 \mathrm{~cm}$, and thicker trees named "ingrowth trees" with DBH $\geq 7 \mathrm{~cm}$. For each tree we recorded: tree species, height (with an accuracy of $0.1 \mathrm{~m}$ ), and for ingrowth trees also DBH. Ingrowth trees were recorded at a whole MP with a radius of $8 \mathrm{~m}$. Small trees were measured and recorded at sub-plots (four satellites at each MP). The reason for this design was to obtain a better estimation of variability in tree number, sizes and species at micro-sites. Thus, four circular subplots (SP), each with a radius of $3 \mathrm{~m}$, were placed around the centre of MPs in the azimuths to the north $\left(0^{\circ}\right)$, east $\left(90^{\circ}\right)$, south $\left(180^{\circ}\right)$ and west $\left(270^{\circ}\right)$. Horizontal distance of each sub-plot from the MP centre was $8 \mathrm{~m}$ (Fig. 2). At each SP, all trees with a height of over $0.1 \mathrm{~m}$ were considered.

\subsection{Data processing and statistical calculations}

The data from the field survey were checked with regard to the completeness and accuracy as well as the logical context. The design of four subplots was dedicated to small trees (each subplot with an area of $28.27 \mathrm{~m}^{2}$ ) and a total area of MP (cca $\left.200 \mathrm{~m}^{2}\right)$ was utilized for ingrowth trees measurements and subsequent calculations. The data from both survey designs were converted to the same area unit (are or hectare) and subsequently further calculation was made for all trees together. Next to evaluation direct measured parameters, as tree number or tree heights, we calculated derived basal area (BA) from measured diameter of breast height (DBH), but only for ingrowth trees.

The results of the survey were expressed as average values for sampling units (i.e. MP or SP). Variability was described using standard deviation (SD). Another result is share of selected trees or MP, calculated as contribution of selected category to total amount (\%). Results were expressed for trees species from tree numbers, basal area and high categories.

\section{Results}

Analyses of the data showed that MPs were established at altitudes from 697 to $1,388 \mathrm{~m}$ a.s.l. Most of the plots $(27.8 \%)$ were located in the altitudinal range between 801 and 900 ma.s.l. (Table 1). The most frequent (30.0\%) aspect was south-east. There were nearly no MPs with a northern aspect and very few MPs were oriented to northwest and west. The MPs were most common (18.9\%) on slopes between $8 \%$ and $9 \%$. Slopes of over $10 \%$ were recorded only at $1 / 5$ of all MPs.

Table 1. Basic terrain characteristics for the monitoring plots (MP).

\begin{tabular}{lccccc}
\hline $\begin{array}{l}\text { Altitude } \\
\text { [m a. s. l. }]\end{array}$ & $\begin{array}{c}\text { Share of MPs } \\
{[\%]}\end{array}$ & $\begin{array}{c}\text { Aspect } \\
{\left[{ }^{\circ}\right]}\end{array}$ & Share & $\begin{array}{c}\text { Slope } \\
{[\%]}\end{array}$ & Share \\
\hline below 700 & 1.1 & $\mathrm{~N}\left(338-22^{\circ}\right)$ & 0 & $0-1$ & 8.9 \\
$701-800$ & 16.7 & $\mathrm{NE}\left(23-67^{\circ}\right)$ & 8.9 & $2-3$ & 26.7 \\
$801-900$ & 27.8 & $\mathrm{E}\left(68-112^{\circ}\right)$ & 23.3 & $4-5$ & 17.8 \\
$901-1,000$ & 17.8 & $\mathrm{SE}\left(113-157^{\circ}\right)$ & 30.0 & $6-7$ & 10.0 \\
$1,001-1,100$ & 16.7 & $\mathrm{~S}\left(158-202^{\circ}\right)$ & 22.2 & $8-9$ & 18.9 \\
$1,101-1,200$ & 8.9 & $\mathrm{SW}\left(203-247^{\circ}\right)$ & 11.1 & $10-11$ & 7.8 \\
$1,201-1,300$ & 7.8 & $\mathrm{~W}\left(248-292^{\circ}\right)$ & 3.3 & $12-13$ & 6.7 \\
over 1,300 & 3.3 & $\mathrm{NW}\left(292-337^{\circ}\right)$ & 1.1 & $>14$ & 3.3 \\
\hline
\end{tabular}

Considering all MPs together (each with an area of $200 \mathrm{~m}^{2}$ ), mean height of small trees was $2.05 \mathrm{~m}$, mean number of small trees was 87 individuals and mean number of species was about five (Table 2) at a plot. As for the SP (an area of about $28.7 \mathrm{~m}^{2}$ ), mean height of small trees was $2.02 \mathrm{~m}$, mean number of small trees was 22 , and number of species was about three. A different situation was found for ingrowth trees, which were measured and also expressed exclusively on the whole area 
of MP. Specifically, mean height of ingrowth trees was $6.6 \mathrm{~m}$, mean number of ingrowth trees about 11 and mean number of species per MP was slightly over two.

Table 2. Basic tree characteristics for the monitoring plots (MP; area of about $200 \mathrm{~m}^{2}$ ) and subplots (SP; area $28.27 \mathrm{~m}^{2}$ ).

\begin{tabular}{llccc}
\hline Tree category & \multicolumn{1}{c}{ Tree characteristics } & Mean \pm SD & Min. & Max. \\
\hline & Mean tree height [m] at SP & $2.02 \pm 0.90$ & 0.28 & 5.30 \\
& Mean tree height [m] at MP & $2.05 \pm 0.65$ & 0.66 & 3.65 \\
Small trees* & Number of trees at SP & $22.2 \pm 19.5$ & 0 & 97 \\
& Number of trees at MP & $87.3 \pm 58.7$ & 3 & 291 \\
& Number of tree species at SP & $3.1 \pm 1.4$ & 1 & 7 \\
& Number of tree species at MP & $5.3 \pm 1.7$ & 2 & 9 \\
\hline & Mean tree height [m] at MP & $6.6 \pm 2.1$ & 0 & 12.5 \\
Ingrowth trees * * Number of trees at MP & $10.7 \pm 9.1$ & 0 & 42 \\
& Number of tree species at MP & $2.2 \pm 1.1$ & 0 & 5 \\
*Small trees - all individuals with DBH $<7 \mathrm{~cm}$ & & & \\
**Ingrowth trees - all individuals with DBH $\geq 7 \mathrm{~cm}$. & & &
\end{tabular}

In total, we recorded 20 tree species, 15 broadleaved and 5 coniferous ones at MPs (Table 3 ). The most frequent (28.9\% of all small trees) species was Norway spruce followed by silver birch (18.6\%), rowan (16.9\%) and goat willow (15.2\%). Four species, i.e. European larch, wild cherry, grey alder and common alder, contributed to total number of trees with a share between 1.8 and $4.8 \%$ each. Share of all other species together was about $5 \%$. In the case of ingrowth trees, Norway spruce contributed with $44.7 \%$ and silver birch with $21.9 \%$. This means that the two species made up as much as $2 / 3$ of all ingrowth trees. Interesting information was found for rowan and goat willow that had a high share (both together $32.1 \%$ ) in small trees, but only a small share (6.4\%) in ingrowth trees. On the other hand, a reverse situation was recorded for Scots pine with a contribution of only $1.1 \%$ to small trees but $10.6 \%$ to ingrowth trees.

Further, our results showed that the density of small trees of over 100 individuals per are $\left(100 \mathrm{~m}^{2}\right)$ was found at $1 / 3$ of all MPs. As many as $25 \%$ of MPs were character- ized with tree density between 61 and 90 individuals (Fig. $3 a)$. At the same time, $23 \%$ of MPs had up to 30 individuals of small trees per are and $20 \%$ of MP between 31 and 60 small trees per are. On the other hand, maximum three ingrow th trees per are were recorded at nearly $1 / 2$ of MPs (Fig. 3b). Only $10 \%$ of MPs had ten and more ingrowth trees per are.

If we consider small trees (although this situation is more-less the same for all trees together, i.e. small and ingrowth individuals), $5-6$ tree species occurred at nearly 1/2 of all MPs (Fig. 4). Nine and more tree species were recorded only at $5 \%$ of MPs. Ingrowth trees were most frequently represented by $1-2$ species $(58 \%$ of MPs) and 3-4 species (33\% of MPs).

The results showed sharp left-sided distribution of tree heights by species (Fig. 5). Spruce dominated among coniferous in all height classes. Interestingly, number of trees of three broadleaved tree species (birch, rowan and willow) in height classes between 1.1 and $5.0 \mathrm{~m}$ was very similar. Comparison of tree height classes by species in ingrowth trees showed that spruce dominated in classes up to $9.0 \mathrm{~m}$ and birch in classes of over $9.0 \mathrm{~m}$ (Fig. 6).

Further, we expressed percentage contribution of tree species to total number of trees in height classes (Fig. 7a). Clearly, contribution of willow and rowan decreased with an increasing height. The reverse situation was found for birch. Contribution of spruce was evident mainly in height classes between 1.1 and $8.0 \mathrm{~m}$. A decreasing trend with increasing tree height classes was recorded not only for the number of trees (from 3,392 to 63 individuals) but also for the number of species (from 18 to 11 species; Fig. $7 b)$. Although contribution of other broadleaved species increased with tree height classes, a reverse trend was found for the number of species in this group (there were as many as eight broadleaved species in the height class up to $1.0 \mathrm{~m}$, but only three in the height class of over $9 \mathrm{~m}$ ).

Table 3. Tree species recorded at the monitoring plots (number of individuals per hectare; tree species are in the descending order of the density of small trees).

\begin{tabular}{|c|c|c|c|c|c|c|c|}
\hline \multirow{2}{*}{ Species } & \multirow{2}{*}{ Latin name } & \multicolumn{2}{|c|}{$\begin{array}{c}\text { Small trees } \\
\text { (i.e. } \mathrm{DBH}<7 \mathrm{~cm} \text { ) }\end{array}$} & \multicolumn{2}{|c|}{$\begin{array}{l}\text { Ingrowth trees } \\
\text { (i.e. } \mathrm{DBH} \geq 7 \mathrm{~cm} \text { ) }\end{array}$} & \multicolumn{2}{|c|}{$\begin{array}{l}\text { All trees } \\
\text { together }\end{array}$} \\
\hline & & $\begin{array}{c}\text { Number } \\
n\end{array}$ & $\begin{array}{c}\text { Share } \\
{[\%]}\end{array}$ & $\begin{array}{c}\text { Number } \\
\mathrm{N}\end{array}$ & $\begin{array}{c}\text { Share } \\
{[\%]}\end{array}$ & $\begin{array}{c}\text { Number } \\
\mathrm{N}\end{array}$ & $\begin{array}{c}\text { Share } \\
{[\%]}\end{array}$ \\
\hline Norway spruce & Picea abies & 2,364 & 28.9 & 203 & 44.7 & 2,567 & 29,7 \\
\hline Silver birch & Betula pendula & 1,527 & 18.6 & 99 & 21.9 & 1,626 & 18.8 \\
\hline Rowan & Sorbus aucuparia & 1,384 & 16.9 & 16 & 3.5 & 1,400 & 16.2 \\
\hline Goat willow & Salix caprea & 1,243 & 15.2 & 13 & 2.9 & 1,256 & 14.5 \\
\hline European larch & Larix decidua & 391 & 4.8 & 28 & 6.1 & 418 & 4.8 \\
\hline Wild cherry & Padus racemosa & 358 & 4.4 & 2 & 0.4 & 359 & 4.2 \\
\hline Grey alder & Alnus incana & 182 & 2.2 & 7 & 1.5 & 188 & 2.2 \\
\hline Common alder & Alnus glutinosa & 176 & 2.2 & 7 & 1.6 & 183 & 2.1 \\
\hline Sycamore & Acerpseudoplatanus & 145 & 1.8 & 6 & 1.3 & 152 & 1.8 \\
\hline Silver fir & Abies alba & 116 & 1.4 & 6 & 1.2 & 122 & 1.4 \\
\hline Aspen & Populus tremula & 113 & 1.4 & 18 & 4.0 & 131 & 1.5 \\
\hline Scots pine & Pinus sylvestris & 90 & 1.1 & 48 & 10.6 & 138 & 1.6 \\
\hline Downy birch & Betula pubescens & 45 & 0.6 & 0 & 0.0 & 45 & 0.5 \\
\hline White willow & Salix alba & 29 & 0.3 & 0 & 0.0 & 29 & 0.3 \\
\hline Common ash & Fraxinus excelsior & 8 & 0.1 & 0 & 0.0 & 8 & 0.1 \\
\hline European beech & Fagus sylvatica & 7 & 0.1 & 1 & 0.1 & 7 & 0.1 \\
\hline Wych elm & Ulmus glabra & 6 & 0.1 & 0 & 0.0 & 6 & 0.1 \\
\hline Small-leaved lime & Tilia cordata & 2 & 0.0 & 0 & 0.0 & 2 & 0 \\
\hline Norway maple & Acerplatanoides & 1 & 0.0 & 0 & 0.0 & 1 & 0 \\
\hline Arolla pine & Pinus cembra & 1 & 0.0 & 0 & 0.0 & 1 & 0 \\
\hline All & Total & 8,187 & 94.7 & 454 & 5.3 & 8,641 & 100.0 \\
\hline
\end{tabular}



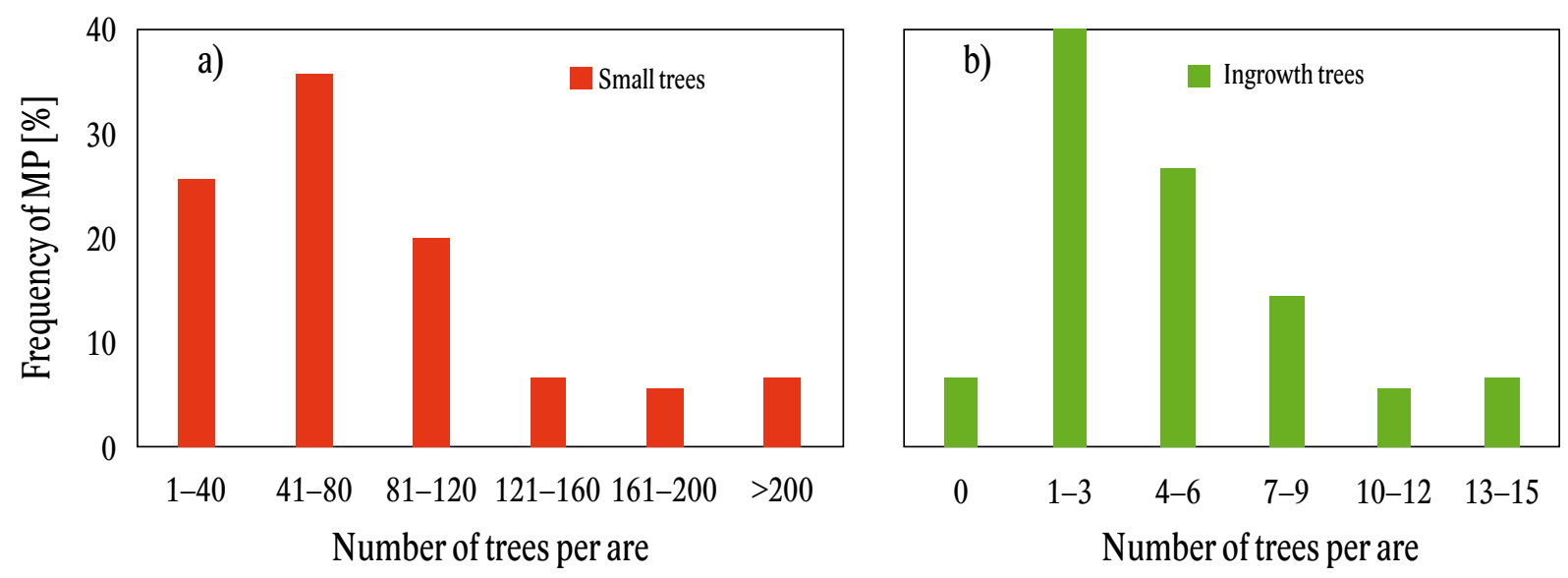

Fig. 3. Frequency of MPs with regard to number of trees per are $\left(100 \mathrm{~m}^{2}\right)$. Small trees and ingrowth trees are shown in separate graphs.

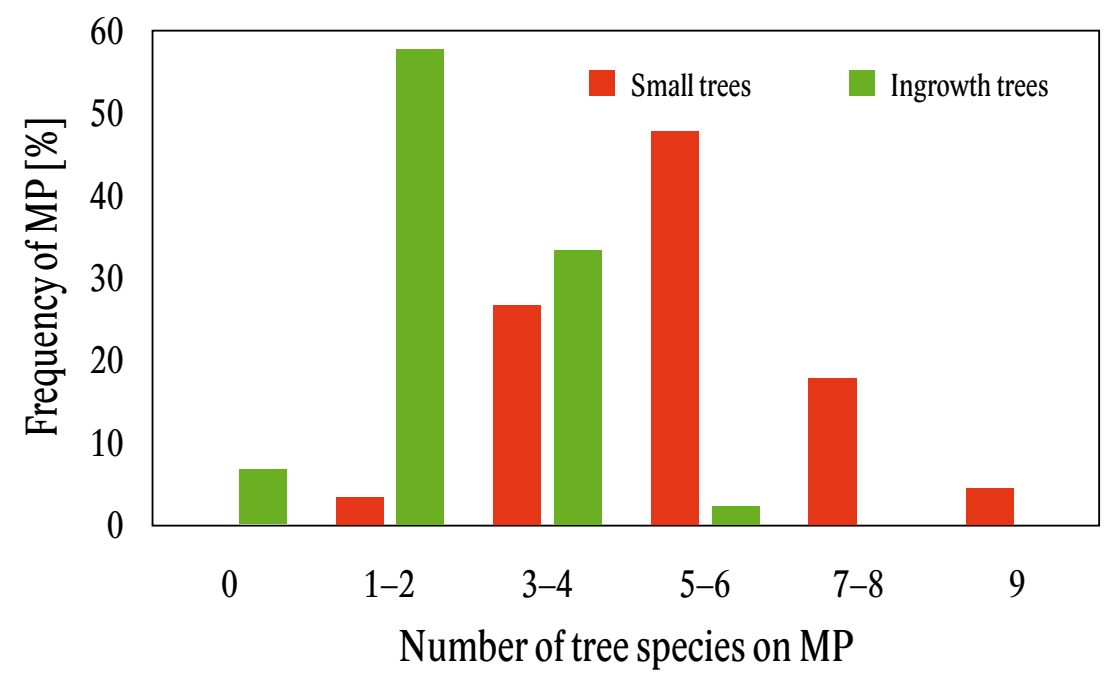

Fig. 4. Frequency of MPs with regard to number of tree species at MP (an area of $200 \mathrm{~m}^{2}$ ). Small trees and ingrowth trees are shown by separate bars.
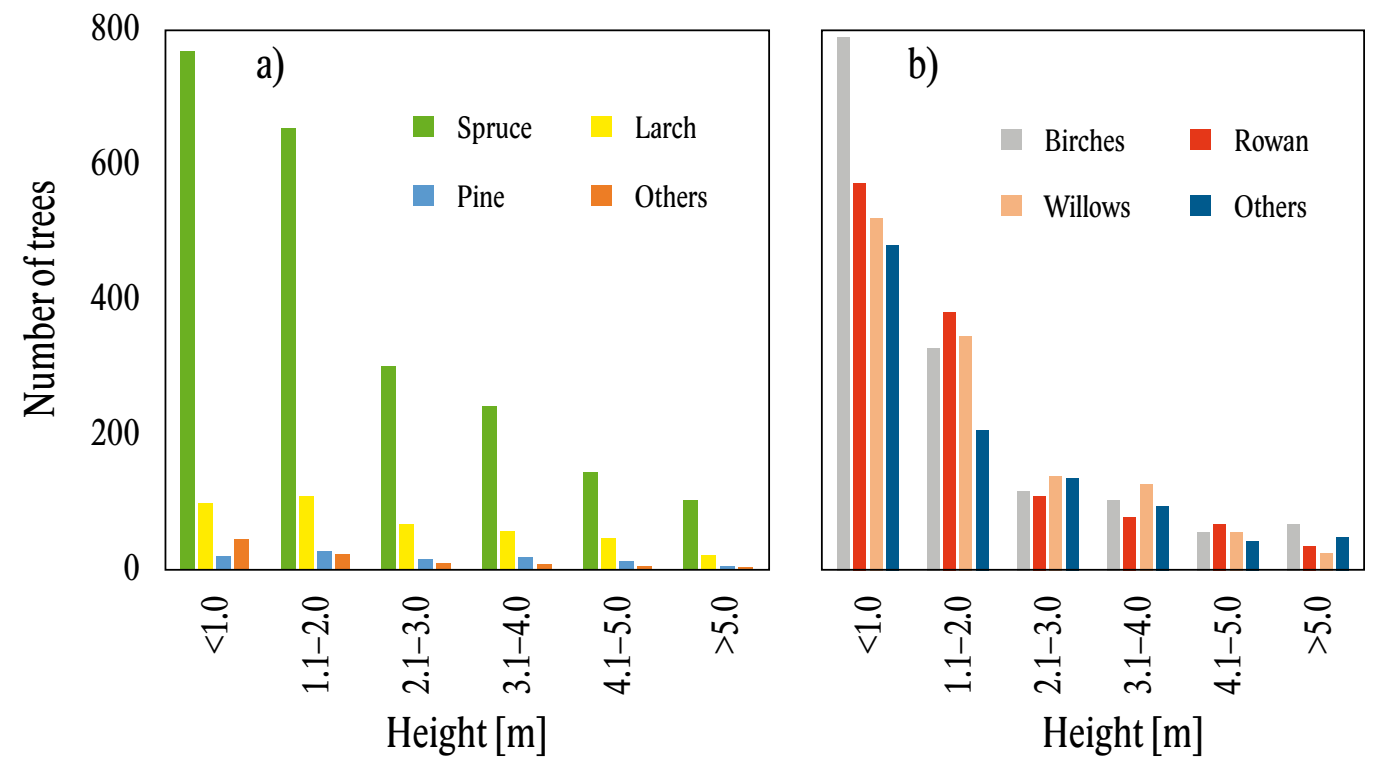

Fig. 5. Height distribution of small trees separately for a) coniferous and b) broadleaved species. Cumulative results for all MPs together. 


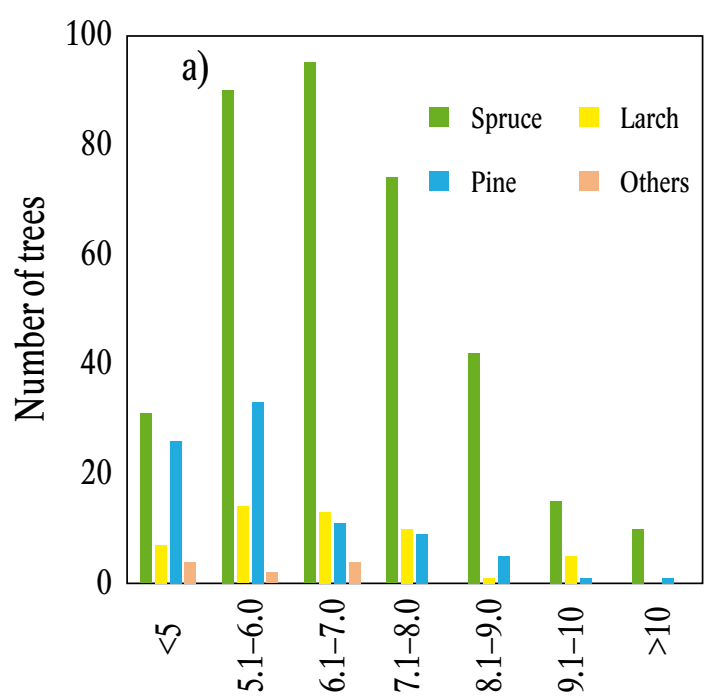

Height $[\mathrm{m}]$

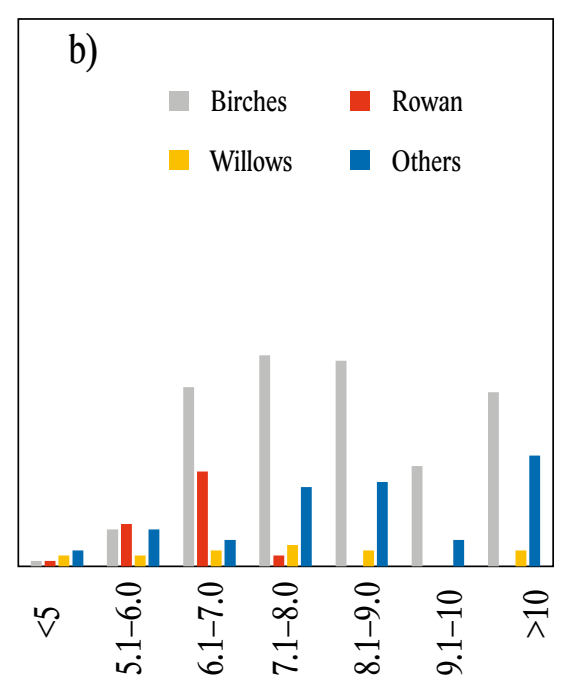

Height $[\mathrm{m}]$

Fig. 6. Height distribution of ingrowth trees separately for (a) coniferous and b) broadleaved species. Cumulative results for all MPs together.

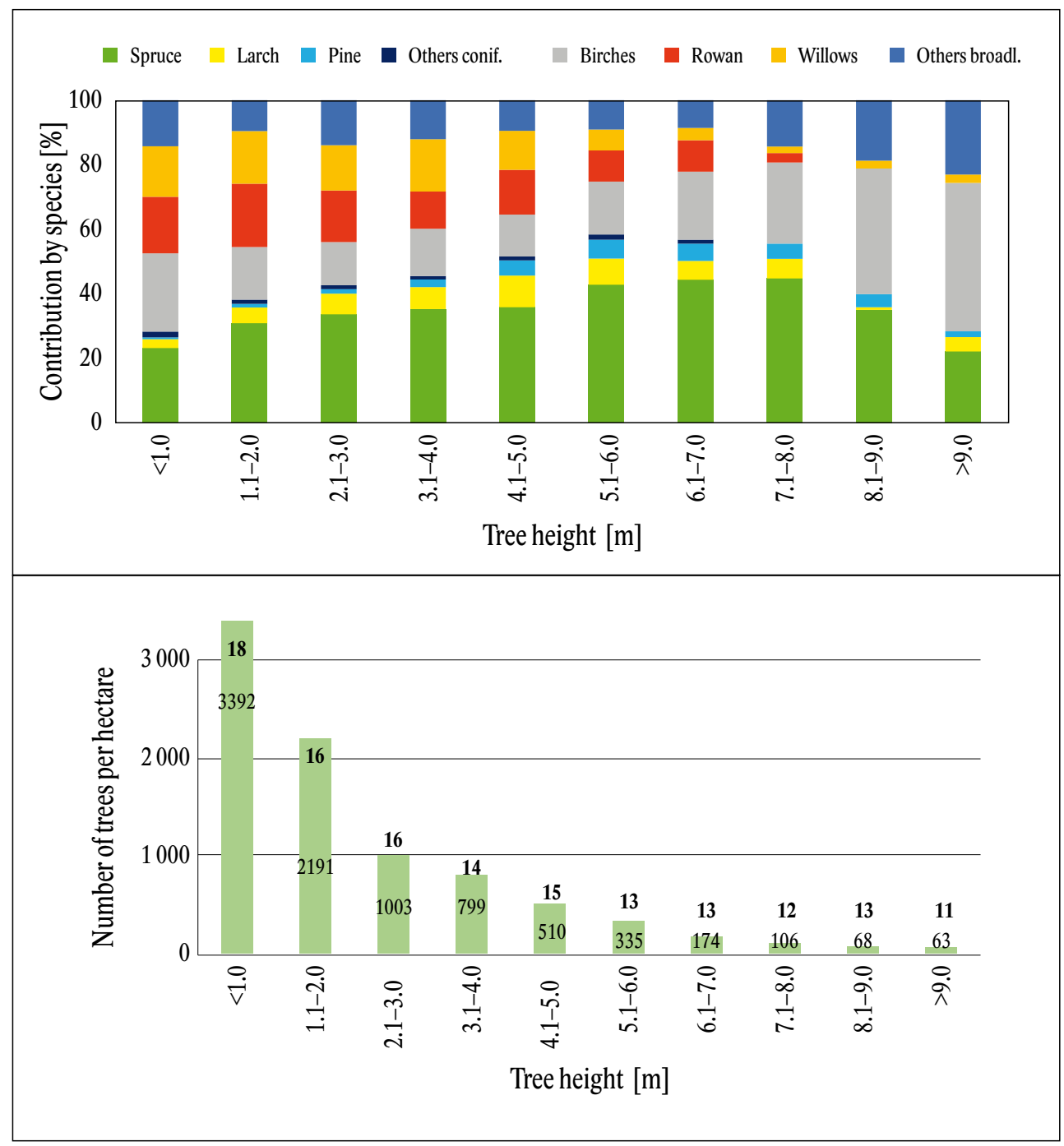

Fig. 7. Tree species composition in height classes considering a) percent contribution of tree species, and b) number of trees (y-axis and lower-placed numbers) together with number of species (higher-placed numbers). Cumulative results for all MPs together. 

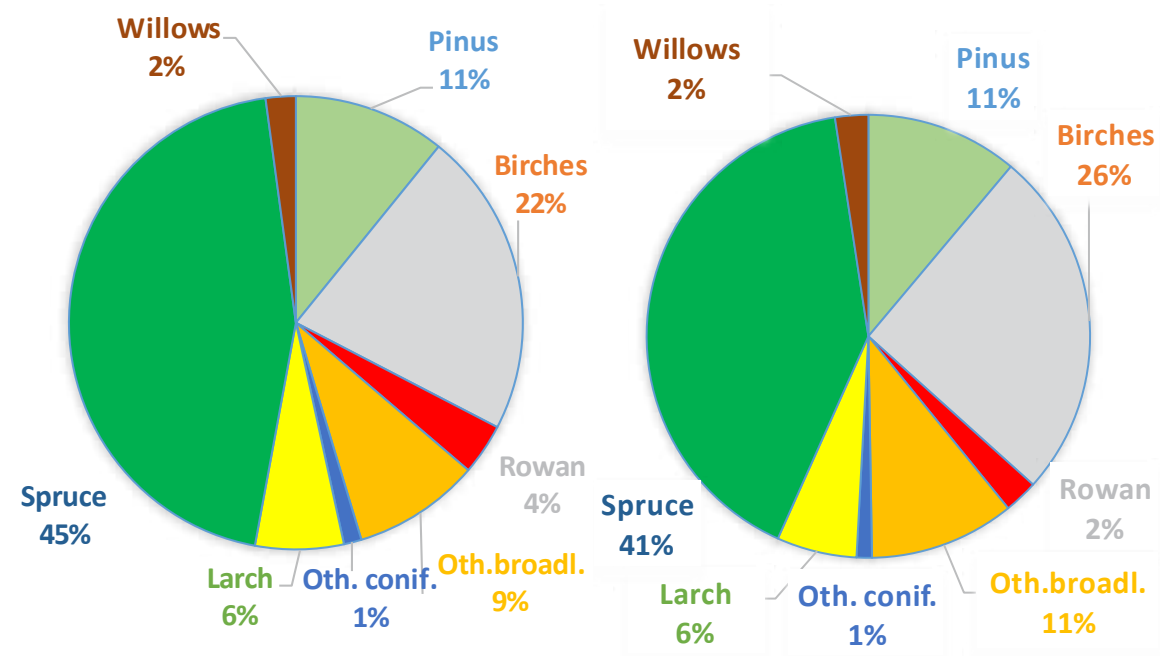

Fig. 8. Tree species composition calculated from a) total number of trees b) total basal area (only data of ingrowth trees were used for the calculation). Cumulative results for all MPs together.

Finally, contribution of tree species (here only ingrowths were included because DBHs of small trees were not measured) to total number of trees (Fig. 8a) and total basal area (Fig. 8b) was analyzed. The highest contribution to either of the two characteristics was found for spruce, followed by birch, pine and larch. While the contribution of some species (pine, larch and willow) was the same from the point of number of trees and basal area, other species (especially spruce, birch and rowan) had a contrasting contribution to number of trees in comparison with their contribution to basal area. Specifically, spruce: $45 \%$ versus $41 \%$ (number of trees against basal area), birches $22 \%$ versus $26 \%$ and rowan $4 \%$ versus $2 \%$. This points out at evident differences between species in their stem size.

\section{Discussion}

\subsection{Tree height structure}

Our results showed that fifteen years after the disturbance episode, young forest stands in the TANAP were still composed by prevailingly small trees with heights up to $1.0 \mathrm{~m}$. This was expected and corresponds with frequently occurred pattern for tree height distribution in young forest stands especially from natural regeneration (e.g. Landsberg \& Sands 2011). The statement, that is needless to say, would be related rather to total number of trees than to total tree biomass. Frequency of tree heights was markedly left-sided. Number of dominant and best growing (as for actual height) trees was very low. This pattern was evident not only for all trees regardless of species but also for nearly all tree species recorded at the post-disturbance area. Sharp left-sided distribution of heights is very typical in young growth stages of forests (e.g. Bondarchuk 2015) and a height lag of the major part of trees in comparison to highest individuals might be related to a variety of internal and external factors (see for instance Landsberg \& Sands 2011). For instance, Szmyt \& Dobrowolska (2015) found lowest values of height variability in severely disturbed forests, while highest variability was in moderately disturbed stands.

Based on knowledge shown in a book of Kacálek et al. (2017), we expected that so called pioneer tree species (especially aspen, birch, rowan and willow) would overgrow coniferous ones (Norway spruce, European larch and Scots pine). However, this phenomenon was not clear due to a number of reasons. Potential differences in actual tree heights or tree heights frequencies between "fast-growing" and "slow-growing" tree species can be diminished by timing of seed germination, competition by weed, browsing by deer or micro-site variability in soil moisture and fertility (possibly also altitudinal gradient). Therefore, we can not make any exact statement as for inter-specific difference in height frequency in our postdisturbance forest stands. On the other hand, we can make a conclusion for stem volume or quantity of aboveground biomass. Our results based on trees with DBH exceeding $7 \mathrm{~cm}$ showed that the birch trees contributed to number of trees by $22 \%$. At the same time, their share to basal area was as much as $26 \%$. This difference between contribution to total number of trees and to basal area indicates that birch trees had thickest stems, and possibly also the largest aboveground biomass of all tree species.

\subsection{Tree species composition}

Our results showed rich tree species composition in young forest stands at the studied mountain sites. Specifically, as many as twenty species, fifteen broadleaves and five coniferous, were recorded at the monitoring plots. Six tree species occurred at more than $50 \%$ of monitoring 
plots and eleven species at more than $10 \%$ plots. Unfortunately, we have no exact scientific data on tree species composition in the TANAP forests before the wind disturbance to perform inter-temporal comparisons. Existing forest management plans show only main tree species, those with low contribution to standing stock are usually omitted. However, according to the estimates of Vološčuk et al. (1994), as much as $80 \%$ of standing stock in Tatra forests was made up by Norway spruce at the end of the 20th century. The rest (nearly 20\%) was represented prevailingly by European larch and Scots pine. Similarly, our previous analyses (Konôpka et al. 2019) based on forest management plans from 1996 showed that Norway spruce contributed to standing stock by about $75 \%$, while Scots pine and European larch made over $20 \%$ of standing stock, and the contribution of other tree species was under $5 \%$. These values suggest that other, especially broadleaved species, had a very small contribution to standing stock. They were just sparsely scattered in forest stands and mostly grew suppressed under the main canopy. Therefore, we can state that the current post-disturbance tree species composition is evidently richer than the one existing before the wind disturbance. Michalová et al. (2017) presented research from the same post-disturbance area in TANAP with regard to tree regeneration. They compared managed and unmanaged sites. Spruce dominated at both site types, and larch and rowan were often admixed, but they found only seven tree species in total. However, their design of measurements did not cover the whole post-disturbance area in the TANAP, but only 100 ha of it. We confirm a dominance of Norway spruce, but we found richer tree species composition with higher proportion of birch and other broadleaves over the whole post-disturbance territory (about 10 thousand ha). Spruce, pine and birch belong to typical pioneer tree species, they often grow on wind post-disturbance areas in Central Europe (e.g. Szmyt \& Dobrowolska 2015) However, their occurrence depends also on the structure of remaining (undamaged) parts of forest stands. For instance, removal of canopy by $10-30 \%$ promotes regeneration of prevailingly shadetolerant tree species (Diaci et al. 2017).

Our finding that the number of tree species decreased with increasing height classes might be hypothetically explained at least in two ways. First, it can be related to diminishing probability of a variety of tree species to occupy new micro-sites with increasing time period after the disaster. Another possible explanation might be gradual elimination of some tree species, especially light demanding or slow-growing ones, due to inter-specific competition. We suppose that the first mentioned assumption would be more probable under the actual conditions in the High Tatra Mts. because inter-specific tree competition seems to be still rather small (with a few exceptions especially in the case of dense sprucedominated clusters).
In general, effects of forest disturbances on flora and fauna biodiversity, including tree species diversity is not clear and might be manifested in contrasting ways. Tree species diversity is perhaps related both to the extent of disturbed area (e.g Ilison et al. 2007) and time period after the episode (Allen et al. 2012). The effects of disturbance (certainly not instantaneous but after a couple of years) on biodiversity were often positive (Thom \& Seidl 2016). In fact, this phenomenon, often named as "disturbance paradox", has been mentioned in several works for a variety of ecosystems (e.g. Wilkinson 1999; Thom \& Seidl 2016). On the other hand, a meta-analysis revealed frequent conflicting or insignificant consequences (Mackey \& Currie 2001). We expect no further increase of tree species diversity in the future, but its gradual decline in TANAP. Most likely, frequency of some trees species, especially aspen, goat willow, and rowan will be reduced by intensive deer browsing (Merganič et al. 2009; Pajtík et al. 2015). In the long run, i.e. in the horizon of $4-5$ decades, we assume a reduction in the share of short-living trees species, namely birch, rowan, goat willow, and eventually other broadleaved species. On the contrary, long-living species (especially spruce, pine and larch or other deciduous trees) will form a "frame" of old stands in the future.

\section{Conclusions}

We may conclude that although the current tree species composition in young stands is richer than in the old predisturbance stands, future forests in the TANAP might converge to composition of the stand which grew here before November 2004. The reason is that contribution of short-living trees species (e.g. birch, rowan, goat willow, and eventually other broadleaved species) in stand composition will be gradually decreasing. Hypothetically, we might assume that potential improvement of ecological stability and resistance of the forests stands to harmful agents (especially wind and bark beetles) in future might be determined by spatial and height structure of forests rather than by tree species composition. Unfortunately, accurate long-term prediction on development of these forest properties is not possible by using recently available tools (e.g. growth simulators). Hence, our assumption can not be proved by any scientific arguments. On the other hand, continuous long-term monitoring of the stands in the TANAP would through more light in knowing processes of post-disturbance succession of forest ecosystems.

\section{Acknowledgements}

The research was supported by the projects $A P V V$-14-0086 and $A P V V$-18-0086 from the Slovak Research and Development Agency, and by grant "EVA4.0", No. CZ.02.1.01/0.0/0.0/16 _019/0000803 financed by OP RDE, as well as by the project 
"Research and innovation for supporting competitiveness of the Slovak forestry sector" (SLOV-LES) financed by the Ministry of Land Management and Rural Development of the Slovak Republic. Dr. Katarína Merganičová is acknowledged for valuable comments and also English language revision on the manuscript.

\section{References}

Allen, M. S., Thapa, V., Arévalo, J. R., Palmer, M. W., 2012: Windstorm damage and forest recovery: accelerated succession, stand structure, and spatial pattern over 25 years in two Minnesota forests. Plant Ecology, 213:1833-1842.

Bondarchuk, S. N., 2015: Study of the Young Growth of Main Forest-forming Coniferous Species in the Primary Forests of the Sikhote-Alin Nature Reserve. Achievements in the Life Sciences, 9:37-50.

Diaci, J., Rozenbergar, D., Fiedej, G., Nagel, T. M., 2017: Challenges of uneven-aged silviculture in restoration of post-disturbance forests in Central Europe: a synthesis. Forests, 8:378.

Díaz, S., Pascual, U., Stenseke, M., Marín-López, B., Watson, R. T., Molnár, Z. et al., 2018: Assessing nature's contributions to people. Science, 359:270272.

Fidej, G., Rozman, A., Diaci, J., 2018: Drivers of regeneration dynamics following salvage logging and different silvicultural treatments in windthrow areas in Slovenia. Forest Ecology and Management, 409:378-389.

Fleischer, P., Pichler, V., Fleischer, P., Holko, L., Máliš, F., Gömöryová, E. et al., 2017: Forest ecosystem services affected by natural disturbance, climate and land-use changes in the Tatra Mountains. Climate Research 73:54-71.

Gregow, H., Laaksonen, A., Alper, M. E., 2017:ncreasing large scale windstorm damage in Western, Central and Northern European forests, 1951-2010. Scientific Reports, 7:1-7.

Homolová, Z., Kyselová, Z., Šoltés, R., 2015: Dynamika vegetácie na kalamitných plochách v spoločenstve Lariceto-Piceetum. Štúdie o Tatranskom národnom parku, 44:191-199.

Ilison, T., Köster, K., Vodde, F., Jogiste, K., 2007: Regeneration development 4-5 years after a storm in Norway spruce dominant forests, Estonia. Forest Ecology and Management, 250:17-24.

Jankovič, J. et al., 2007: Projekt revitalizácie lesných ekosystémov na území Vysokých Tatier postihnutom veternou kalamitou dňa 19.11.2004. Zvolen, NLC, 75 p.

Kacálek, D., Mauer, O., PodrázskýV., Slodičák, M. et al., 2017: Meliorační a zpevňující funkce lesních dřevin. Lesnická práce, 300 p.

Konôpka, B., Zach, P., Kulfan, J., 2016:Wind-an important ecological factor and destructive agent in forests. Lesnícky časopis - Forestry Journal, 62:123-130.
Konôpka, B., Šebeň, V., Pajtík, J., 2019: Species composition and carbon stock of tree cover at a postdisturbance area in Tatra National Park, Western Carpathians. Mountain Research and Development, 39:71-80.

Koreň, M., 2005: Vetrová kalamita 19 novembra 2004: nové pohl'ady a konsekvencie. Tatry, Special issue, 6-29.

Kulla, L., Šmelko, Š., Šebeň, V., Rizman, I., Jankovič, J., 2007: Monitoring poškodených lesných ekosystémov Vysoké Tatry 2007. Metodika terénneho zberu údajov. Zvolen, NLC, 42 p.

Landsberg, J., Sands, P., 2011: Physiological Ecology of Forest Production. Principles, Processes and Models. Amsterdam, Elsevier, 331 p.

Mackey, R. L., Currie, D. J., 2001: The diversity-disturbance relationship: is it generally strong and peaked? Ecology, 82:3479-3492.

Merganič, J., Russ, R., Beranová, J., Merganičová, K., 2009: Assessment of the impact of deer on the diversity of young trees in forest ecosystems in selected localities of the Czech Republic. Ekológia (Bratislava), 28:424-437.

Michalová, Z., Morrissey, R., Wohlgemuth, T., Bače, R., Fleischer, P., Svoboda, M., 2017: Salvage-logging after windstorm leads to structural and functional homogenization of understory layer and delayed spruce tree recovery in Tatra Mts., Slovakia. Forests, 8:88.

Ministry of Agriculture and Rural Development of the Slovak Republic, 2019: Report on Forestry in the Slovak Republic per year 2019 (Green Report). Bratislava, MARD, $66 \mathrm{p}$.

Mitchell, S. J., 2013: Wind as a natural disturbance agent in forests: a synthesis. Forestry - an International Journal of Forest Research, 86:147-157.

Orman, O., Dobrowolska, D., Szwagrzyk, J., 2018: Gap regeneration patterns in Carpathian old-growth mixed beech forests - Interactive effects of spruce bark beetle canopy disturbance and deer herbivory. Forest Ecology and Management, 430:451-459.

Pajtík, J., Konôpka, B., Bošela, M., Šebeň, V., Kaštier, P., 2015: Modelling forage potential for red deer: A case study in post-disturbance young stands of rowan. Annals of Forest Research, 58:91-107.

Seidl, R., Schelhaas, M. J., Rammer, W., Verkerk, P. J., 2014: Increasing forest disturbances in Europe and their impact on carbon storage. Nature Climate Change, 4:806-810.

Szmyt, J., Dobrowolska, D., 2016: Spatial diversity of forest regeneration after catastrophic wind in northeast Poland. iForest - Biogeosciences and Forestry, 9:414-421. 
Šebeň, V., 2007: Praktická realizácia terestrickej monitorovacej siete na sledovanie vývoja poškodených lesných ekosystémov po veternej kalamite. Seminár: PokalamitnývýskumvTANAPe. Tatranská Lomnica, 25.10.2007.

Šebeň, V., 2010a: Prirodzená obnova po kalamite z novembra 2004 vo Vysokých Tatrách. In: Výskum smrečín destabilizovaných škodlivými činitel'mi. Vedecký recenzovaný zborník. Zvolen, NLC, LVÚ, Zvolen, p. 297-308.

Šebeň, V., 2010b: Podiel a skladba prežívajúcej umelej obnovy na kalamitisku vo Vysokých Tatrách. In:Výskum smrečín destabilizovaných škodlivými činitel'mi. Vedecký recenzovaný zborník. Zvolen, NLC, LVÚ, Zvolen, p. 309-320.
Šebeň, V., Bošela, M., Kulla, L., 2011: Terrestrial network for monitoring of revitalisation processes of the windfall and its surrounding in the High Tatra. Studies on Tatra National Park, 10:13-24.

Šebeň, V., Konôpka, B., 2019: Vývoj kalamitiska vo Vysokých Tatrách do roku 2019 podla terestrického monitoringu. Štúdie Tatranského národného parku, 13:9-25.

Thom, D., Seidl, R., 2016: Natural disturbance impacts on ecosystem services and biodiversity in temperate and boreal forests. Biological Reviews, 91:760-781. Vološčuk, I. et al., 1994:Tatranský národný park. Martin, Gradus, 558 p.

Wilkinson, D. M., 1999. The disturbing history of intermediate disturbance. Oikos, 84:145-147. 